\title{
FLORES, Conceição (Org.). Mulheres e literatura: ensaios. Natal: EDUnP, 2013. $436 \mathrm{p}$.
}

Mulheres e literatura: ensaios (2013) é uma coletânea que resume muitos dos artigos apresentados em conferências ou comunicações do congresso bienal Mulher e Literatura, realizado pela Universidade Potiguar, em 2011. Organizado pela Professora Doutora Conceição Flores, este livro apresenta como ponto de partida as conferências das homenageadas neste Congresso, as poetas Maria Teresa Horta e Diva Cunha. As suas conferências somam-se à de renomados professores e pesquisadores da literatura de autoria feminina e do feminino na literatura. Publicada pela editora da UNP (EDUNP), registra a importância do grande encontro que foi o IV Seminário Internacional Mulher e Literatura (sendo este o XIII Seminário Nacional), importante evento na agenda das discussões sobre gênero desde a criação do GT Mulher e Literatura, filiado à Associação Nacional de Pós-Graduação e Pesquisa em Letras e Linguística (ANPOLL), realizado, nessa ocasião, em Natal, capital do Rio Grande do Norte. Constatar o valor que estes ensaios reunidos apresentam, é reafirmar a inegável e grande contribuição que os estudos de Gênero trouxeram para um repensar da literatura que se tem constatado a partir dos estudos feministas e dos movimentos em favor das minorias. É pertinente lembrar que foi a partir destes estudos que congressos como o acima mencionado passaram a figurar nos calendário de grandes universidades e centros de pesquisas, proporcionando discussões que por muito tempo ficaram à sombra de um cânone literário masculino. Basta mencionar que muitas das participantes deste livro, como Constância Lima Duarte, Elódia Xavier, Luiza Lobo, entre outros nomes também de grande valor para os estudos de Gênero, trouxeram novamente para o mercado editorial romances e poesias de autoras esquecidas, ou pouco divulgadas nos meios editorias, como Narcisa Amália, Maria Firmina dos Reis, dentre tantas outras, cujos livros ficaram por muito tempo esquecidos em estantes de bibliotecas. A maioria dos ensaios tematiza a trajetória, a memória e a escrita de poetas e ficionistas: como Alina Paim, Clarice Lispector, Conceição Evaristo, Lya Luft, Maria Velho da Costa, Helena Parente Cunha, Emile Brönte, Edwiges Danticat, dentre outras não menos importantes. As discussões, de extrema riqueza para estudantes, professores e pesquisadores da área, refletem um trabalho que tem como principal objeitvo dar visibilidade à mulher como produtora e também sujeito de saberes culturais. De acordo com as palavras de Constância Lima Duarte, professora da Univseridade Federal de Minas Gerais e uma das conferencistas do Seminário Internacional: “[...] a descoberta de diários, cartas, testamentos e até antigos jornais, tinha o poder de acrescentar novos informes, e atribuir novos significados aos textos deixados pelas escritoras. [...] Durante séculos trancadas em casa, vigiadas até por escravos e pelos filhos, as mulheres viveram sujeitas a autoridade e também à autoria masculina. Por isso foi tão longa a conquista de sua escrita." (Texto contra capa). Confirmam as palavras de Constâncias, estudos como o de Isabel Lousada; este aponta a intensa participação das mulheres portuguesas na proclamação da república, trazendo à tona nomes como Adelaide Cabete e Alda Gurreiro Machado, autoras de narrativas sobre a participação feminina naquele momento histórico para Portugal. A diversidade de estudos da coletânea Mulheres e literatura: ensaios está estruturada em cinco partes, quais sejam: "A palavra das homenageadas", "Memórias", "Representações", "Trajetórias" (a parte mais longa) e, por fim, um "Post scriptum": uma entrevista com Diva Cunha. O livro nada tem de "ressentido", para lembrar aqui o termo usado por Harold Bloom em O cânone ocidental, ao falar sobre os estudos de Gênero. É, antes, uma prova cabal, dentre muita nos dias atuais, de que sérias e empenhadas pesquisadoras e pesquisadores aceitaram a proposta de refletir sobre o universo feminino, seja no âmbito autoral seja no âmbito das representações deste universo, e dela angariam produtiva colheita. Assim, para todos os leitores, mas, sobremaneira para as Liliths e Evas, colhamos este fruto, resultante das conquistas feministas, de tempos não muito logínquos, quando foi preciso queimar sutiãs. Conquistas regadas e bem adubadas, neste livro-fruto, que é o Mulheres e literatura: ensaios (2013) pelo sábio olhar compilador de Conceição Flores.

ALDinida MEDEIROS Universidade Estadual da Paraíba

Recebido: 30 janeiro 2014 Aprovado: 14 fevereiro 2014 Contato: aldinidamedeiros@gmail.com 